\title{
Molecular docking studies of Alpinia galanga metabolites against human placental aromatase for estrogen-dependent breast cancer treatment
}

\section{Joe Anthony H. Manzano ${ }^{1,2}$, Cecil Laurence M. Cruz III',3, Allan Patrick G. Macabeo ${ }^{1 *}$}

\author{
${ }^{1}$ Laboratory for Organic Reactivity, Discovery, and Synthesis (LORDS), Research \\ Center for the Natural and Applied Sciences, University of Santo Tomas, España Blvd., \\ Manila 1015 Philippines \\ 2Department of Biological Sciences, College of Science, University of Santo Tomas, \\ España Blvd., Manila 1015 Philippines \\ ${ }^{3}$ Senior High School Department, University of Santo Tomas, España Blvd., Manila \\ 1015 Philippines
}

Keywords: Alpinia galanga, aromatase inhibitors, breast cancer, molecular docking, human placental aromatase 


\section{ABSTRACT}

Breast cancer is the leading cause of cancer-related deaths among women. With the clinical success of several synthetic aromatase inhibitors (Als) as therapeutic agents in post-menopausal estrogen receptor-positive breast cancer, natural products have been tapped in search of chemically diverse compounds with potential better effectiveness against aromatase while conferring reduced adverse effects. Alpinia galanga is among the Philippine native medicinal plants with extensive studies on its phytopharmacological properties yet reports on its human placental aromatase inhibitory activity remain rudimentary. Thus, a total of 119 database-derived A. galanga secondary metabolites was molecularly docked onto the catalytic site of human placental aromatase using the UCSF Chimera platforms according to the AutoDock Vina Broyden-Fletcher-GoldfarbShanoo (BFGS) algorithm. Drug-likeness was assessed in silico using SwissADME. Of the screened compounds, galanolactone (1), 4-(3,4-dimethoxy-trans-cinnamoyl)-transcinnamic acid (2), isocoronarin D (3), quercetin (4), $\beta$-sitosterol (5), (E)-8ß,17-epoxylabd12-ene-15,16-dial (6), galangin (7), labda-8(17),12-diene-15,16-dial (8), 7-(4-Hydroxy-3methoxyphenyl)-1-phenylhept-4-en-3-one (9), and 3,5,7-trihydroxy-4-methoxyflavanone (10) conferred highest binding affinities against aromatase ranging from binding energies of -8.7 to $-8.0 \mathrm{kcal} / \mathrm{mol}$ with notable formed hydrogen bonds and interactions against key amino acid residues. Top-ranked compounds exhibited druggability with at most one violation of the Lipinski Rule of Five (LRo5). Overall, the study indicates the potential of top $A$. galanga secondary metabolites as promising drug pharmacophores in developing therapeutics against breast cancer. 


\section{INTRODUCTION}

Cancer remains among the deadliest maladies to mankind. In women, breast cancer ranks second as the leading cause of cancer-related deaths (American Cancer Society 2020). In the Philippines, the highest breast cancer incidence in Asia is observed with $16 \%$ of all cancer cases (Kim et al. 2015). With a survival rate of less than $50 \%$, it kills 300,000 lives per year (Department of Health 2021). According to Youlden and colleagues (2014), these statistics are expected to increase every year.

Human placental aromatase, a key enzyme implicated in postmenopausal estrogen receptor-positive breast cancer, catalyzes the final step in estrogen biosynthesis from the conversion of androstenedione and testosterone. Estrogens in general are known to promote cancer cell growth, proliferation, metastasis, and recurrence in hormonedependent breast cancers. Thus, reduction of estrogen levels via inhibition of the catalytic activity of aromatase is recognized as one of the effective therapeutic armamentariums in breast cancer management (Amir et al. 2011; Lonning et al. 2013). Although estrogen production in the ovaries ceases after menopause, surrounding tissues continue to produce adequate concentrations to stimulate tumor growth and eventual proliferation. Globally, $50-80 \%$ of breast cancers are estrogen-dependent where tumor cell proliferation is due to estrogen binding to its receptor. Thus, estrogen receptor-positive breast cancer

therapy through use of aromatase inhibitors (Als) is widely recognized as an emerging less invasive treatment modality (Brueggemeier et al. 2001; Chumsri et al. 2011). 


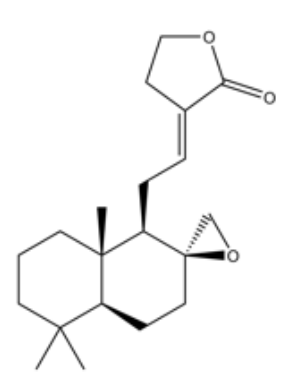

galanolactone (1)

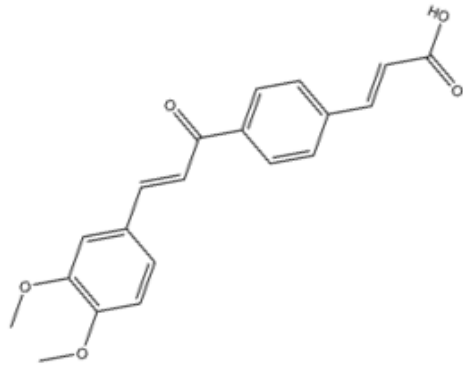

4-(3,4-dimethoxy-trans-cinnamoyl)-transcinnamic acid (2)

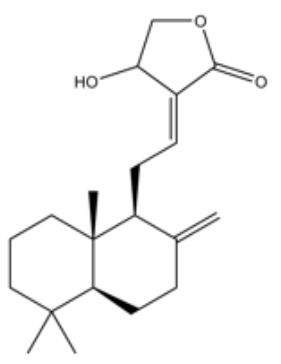

isocoronarin D (3)

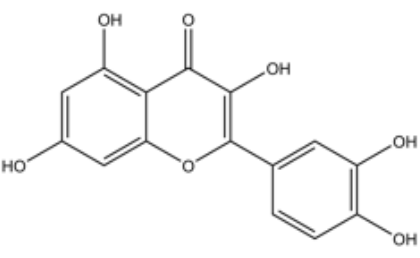

quercetin (4)

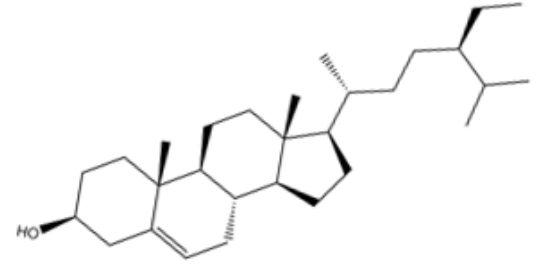

$\beta$-sitosterol (5)

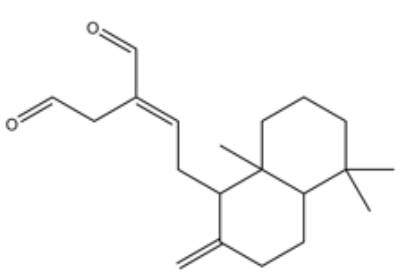

labda-8(17),12-diene-15,16-dial (8)

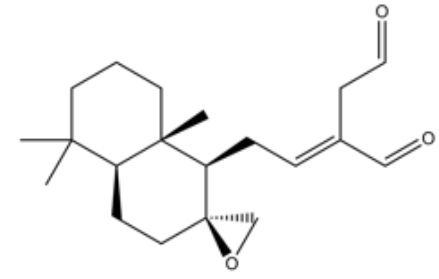

(E)-8ß,17-epoxylabd-12-ene-15,16-dial (6)

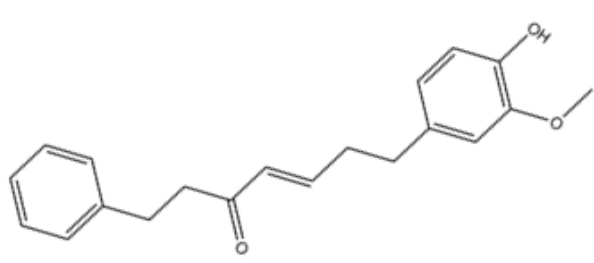

7-(4-hydroxy-3-methoxyphenyl)-1-phenylhept-4en-3-one (9)

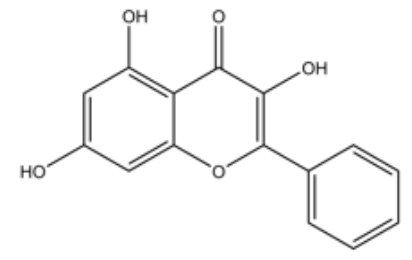

galangin (7)

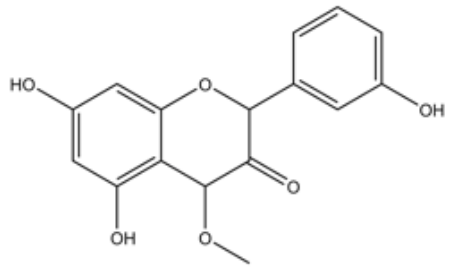

3,5,7-trihydroxy-4methoxyflavanone (10)

Figure 1. Top ranking $A$. galanga compounds $\mathbf{1 - 1 0}$ with in silico inhibitory activity against aromatase.

Alpinia galanga (L.) Willd. (Zingiberaceae), commonly known as langkawas, is a medicinal plant found in Southern Luzon provinces in the Philippines. It is also used as an Asian spice due to its aromatic odor and spicy flavor. In Chinese traditional medicine, it is used to remedy gastrointestinal ailments such as stomachache, dyspepsia and frigid gastro-vomiting (Xiao-Lu et al. 2009). Natural products isolated from the genus Alpinia have shown broad range of biological activities such as anticancer, antioxidant, antibacterial, antiviral, and cardiovascular health-promoting properties (Zhang et al., 2016). Yet studies on inhibitory activities against human placental aromatase remain 
rudimentary. As part of our efforts to explore natural products with anti-cancer properties (Macabeo et al. 2014; Macabeo et al. 2017; Phukhamsakda et al. 2019; Quimque et al. 2020a; Malaluan et al. 2022), we report herein the anti-human placental aromatase activities of $A$. galanga constituents through molecular docking studies (Figure 1).

\section{MATERIALS AND METHODS}

\section{Ligand selection and preparation}

A library of 119 secondary metabolites previously identified from Alpinia galanga was screened against human placental aromatase (Appendix Figure I). The ligands in SMILES notation were converted to SYBYL mol2 file format and optimized in Avogadro (version 1.2.0). The prepared ligands were added to UCSF Chimera (version 1.14) for molecular docking (Magpantay et al. 2021).

\section{Target protein preparation and minimization}

The crystallized three-dimensional structure of human placental aromatase in complex with androstenedione (PDB ID: 3EQM, chain A) was fetched from the Protein Data Bank (https://www.rcsb.org/) using UCSF Chimera (version 1.14) (Leechaisit et al. 2019; de Leon et al. 2021). Non-standard residues, co-crystallized ligands and water molecules were removed to clear the active pocket. Protein minimization was performed using the steepest descent method in tandem with the conjugate gradient method protocol. A total of 100 steps (step size at 0.02 Angstrom) was utilized. Charges were obtained based on Amber's Antechamber module computation using the Gasteiger charge mode (Wang et al. 2006; Fernandez et al. 2021). 


\section{Molecular docking studies}

Prepared ligands 1-119 in mol2 format was inputted to UCSF Chimera together with the minimized protein (Pettersen et al. 2004). A 3D grid box which encompasses the active site of the protein and as predicted by $\mathrm{COACH}$ algorithms in AutoDock Vina was generated. The actual docking was performed using Broyden-Fletcher-Goldfarb-Shanno (BFGS) algorithm. Visualization of docked complexes was carried out in BIOVIA Discovery Studio (version 4.1) (Yang et al. 2013).

\section{Drug-likeness, ADME and pharmacokinetic profile}

Absorption, distribution, metabolism and excretion (ADME) properties of top compounds were computationally predicted using SwissADME (http://www.swissadme.ch/index.php). Pharmacokinetic profiles of compounds were evaluated according to Lipinski's rule of five which determines drug-likeness based on the following criteria: molecular weight $<500$, calculated lipophilicity $(\mathrm{MLogP})<5$, number of hydrogen-bond acceptors $<10$, and number of hydrogen bond acceptors < 5 (Macabeo et al. 2020; Quimque et al. 2020b).

\section{RESULTS AND DISCUSSION}

A total of 119 secondary metabolites from Alpinia galanga which include polyphenolics, diterpenoids, flavonoids, sterols, cinnamic acids and alkaloids were molecularly docked onto the androstenedione-binding active domain of aromatase (Appendix Table I).

\section{Molecular docking against human placental aromatase}


Molecular docking was performed to investigate binding modalities of the Alpinia galanga compounds and the target protein, human placental aromatase. Inhibition of aromatase is a crucial modality in the prevention of growth stimulation effect of estrogens in postmenopausal breast cancer. So, aromatase inhibitors have been investigated and developed as anti-breast cancer therapeutics. Generally, two types of Als are known and are classified based on their mechanism of action - steroidal and nonsteroidal Als. The latter bind reversibly to the active site via noncovalent bonds while the former one may interact to the active site through competitive manner via covalent interactions (Yadav et al. 2015; Adhikari et al. 2017).

In our study, the top ten $A$. galanga compounds exhibited binding energies ranging from $-8.7 \mathrm{kcal} / \mathrm{mol}$ to $-8.0 \mathrm{kcal} / \mathrm{mol}$ (Table 1 ). The drug control androstenedione showed -9.4 $\mathrm{kcal} / \mathrm{mol}$ binding energy (Appendix Table I). Diterpenoid galanolactone (1) conferred the highest binding affinity. Its non-methylated cyclohexyl moiety (ring B) interacted with Val373 and Val370 via alkyl interactions. The fused ring A cyclohexyl group and its dimethyl group also showed alkyl interactions with Cys437. Both Ala306 and Ile133 formed alkyl bonding with the furanone moiety (Figure 2). 
Table 1. Binding affinities and interacting residues of $A$. galanga compounds against aromatase.

\begin{tabular}{|c|c|c|c|}
\hline Compound & $\begin{array}{l}\text { Binding affinity } \\
\text { (kcal/mol) }\end{array}$ & Hydrogen bond & Other Interactions \\
\hline galanolactone (1) & -8.7 & None & $\begin{array}{c}\text { Val373, Ala306, lle133, Val370, } \\
\text { Cys437 (alkyl) }\end{array}$ \\
\hline $\begin{array}{l}\text { 4-(3,4-dimethoxy- } \\
\text { trans-cinnamoyl)- } \\
\text { trans-cinnamic acid } \\
(2)\end{array}$ & -8.4 & Met374, Gly439 & $\begin{array}{c}\text { Ala306 (pi-sigma), Leu477, Val370, } \\
\text { Cys437, Leu152, Ile132, Ile133, } \\
\text { Phe148 (alkyl, pi-alkyl) }\end{array}$ \\
\hline isocoronarin D (3) & -8.5 & None & $\begin{array}{l}\text { Ile132, Ala438, Phe148, Cys437, } \\
\text { Ile133, Ala306, Trp224 (alkyl, pi-alkyl), } \\
\text { Leu477, Leu372 (hydrophobic) }\end{array}$ \\
\hline quercetin (4) & -8.3 & Met374 & Ile133 (pi-sigma), Ala438 (pi-alkyl) \\
\hline$\beta$-sitosterol (5) & -8.3 & Cys 437 & $\begin{array}{l}\text { Ile133, Val370, Ala438, Ile132, } \\
\text { Met303, Ala307, Phe203, Leu152, } \\
\text { Phe148, Ala306 (alkyl, pi-alkyl) }\end{array}$ \\
\hline $\begin{array}{l}(E) \text {-8ß,17-epoxylabd- } \\
\text { 12-ene-15,16-dial (6) }\end{array}$ & -8.3 & Arg115, Met374 & $\begin{array}{l}\text { Ala306, lle133, Cys437, Phe148, } \\
\text { Ala438, Ile132 (alkyl, pi-alkyl) }\end{array}$ \\
\hline galangin (7) & -8.2 & Arg115, Leu372 & $\begin{array}{l}\text { Phe134, Trp224 (pi-pi), lle133 (pi- } \\
\text { sigma), Ala306 (pi-alkyl) }\end{array}$ \\
\hline $\begin{array}{l}\text { labda-8(17),12-diene- } \\
\text { 15,16-dial (8) }\end{array}$ & -8.1 & Met374, Arg115 & $\begin{array}{l}\text { Cys437, Ala306, lle133, Trp224, } \\
\text { Phe221 (alkyl, pi-alkyl) }\end{array}$ \\
\hline $\begin{array}{l}\text { 7-(4-hydroxy-3- } \\
\text { methoxyphenyl)-1- } \\
\text { phenylhept-4-en-3- } \\
\text { one (9) }\end{array}$ & -8.1 & Ala438 & $\begin{array}{l}\text { Ala306 (pi-sigma), Ala307, Phe148, } \\
\text { Cys437, Ile113, Leu152 (alkyl, pi-alkyl) }\end{array}$ \\
\hline $\begin{array}{l}\text { 3,5,7-trihydroxy-4- } \\
\text { methoxyflavanone } \\
\text { (10) }\end{array}$ & -8.0 & $\begin{array}{l}\text { Asp309, Arg115, } \\
\text { Met374, Leu477 }\end{array}$ & $\begin{array}{l}\text { Ile133 (pi-sigma), Phe134 (pi-pi } \\
\text { stacked), Ala306 (pi-alkyl) }\end{array}$ \\
\hline
\end{tabular}



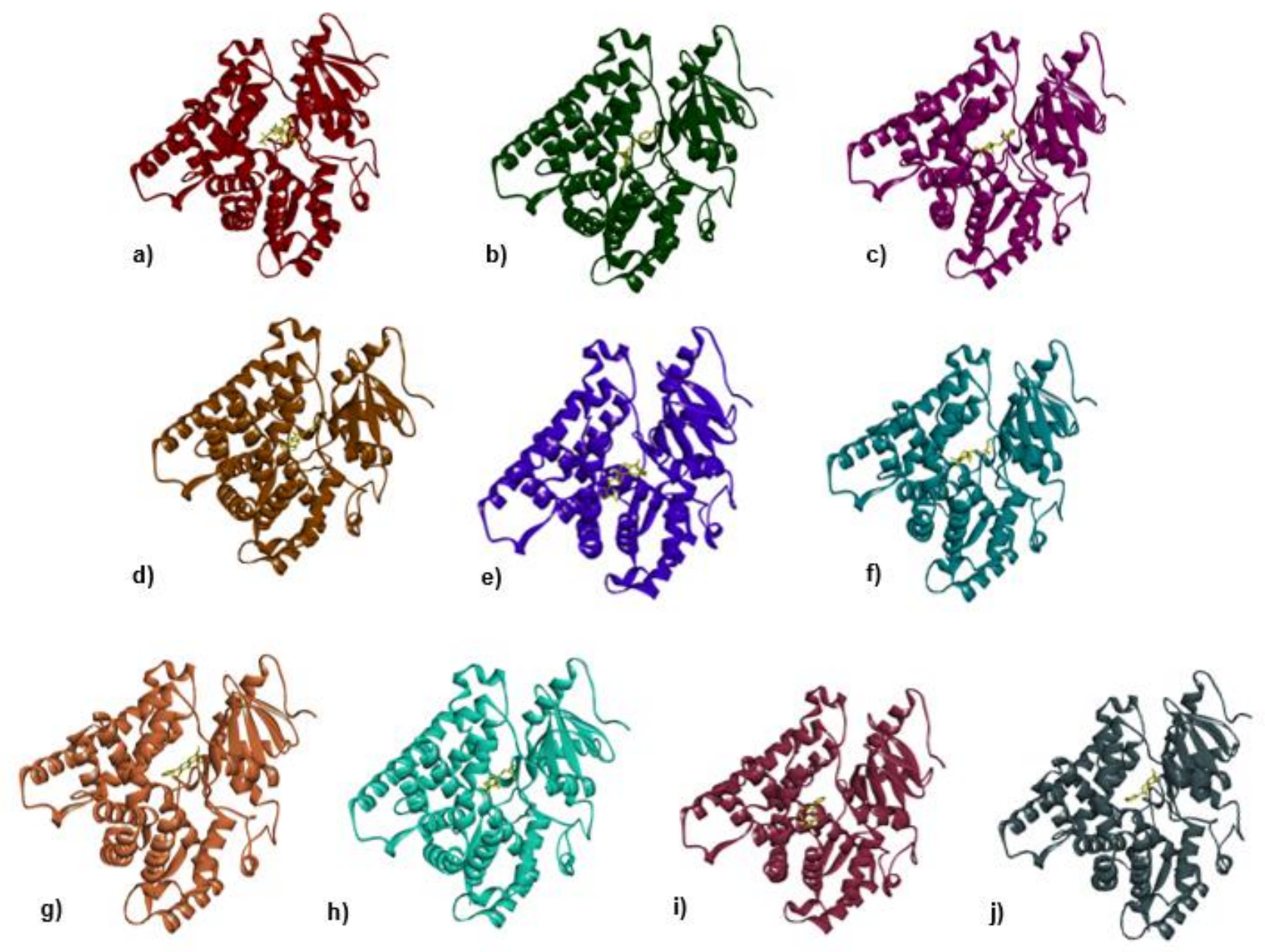

Figure 2. Docked poses of (a) galanolactone (1), (b) 4-(3,4-dimethoxy-transcinnamoyl)-trans-cinnamic acid (2), (c) isocoronarin D (3), (d) quercetin (4), (e) $\beta$ sitosterol (5), (f) (E)-8ß,17-epoxylabd-12-ene-15,16-dial (6), (g) galangin (7), (h) labda8(17),12-diene-15,16-dial (8), (i) 7-(4-Hydroxy-3-methoxyphenyl)-1-phenylhept-4-en-3one (9), and (j) 3,5,7-trihydroxy-4-methoxyflavanone (10) against aromatase (PDB ID: 3EQM). 
Table 2. Summary of key amino acid domains in the active side and side residues of aromatase (Park et al. 2013).

\section{Location Type of Interaction Key Amino Acids}

Active Site

Hydrogen Bond

Side

Residues
Met107, Arg115, Ile132, Ile133, Phe134, Trp141, Arg145, Phe148, Leu152, Leu188, Arg192, Val214, Ile217, Gln218, Tyr220, Phe221, Asp222, Trp224, Gln225, Leu228, Glu302, Met303, Ile305, Ala306, Ala307, Pro308, Asp309, Thr310, Met311, Ser312, Val313, Ser314, Val369, Val370, Asp371, Leu372, Val373, Met374, Arg375, Ile398, Pro429, Phe430, Phe432, Arg435, Glu436, Phe437, Ala438, Ala443, Leu477, Ser478, Leu479, and His480

Met374, Leu372, Arg115, Thr310, Ala306, Leu377, Asp309, Leu479, and Ser478

Phe134, Phe221, Trp224, Ile305, Ala306, Val370, Val373, Met374, Leu477

$(-)=$ not specified

Previous studies have identified key interacting amino acids for ligands in the aromatase active site such as Met374, Arg115, Ile133, Phe134, Phe221, Trp224, Ala306, Thr310, Asp309, Val370, Val373, Leu477, and Ser478 (Ghosh 2009; Roy \& Roy 2010). A more recent study added more key residues in both the active site and its periphery with 
specified side residues that need to be involved in hydrogen bonding to confer inhibitory activity (Park et al. 2013) (Table 2).

Comparing the data on key amino acid residues by Park and colleagues (2013) and the results of our interaction analysis, 3,5,7-trihydroxy-4-methoxyflavanone (10) displayed the most hydrogen bonding to the key domains with four hydrogen bonds, followed by $(E)-8 ß, 17-e p o x y l a b d-12-e n e-15,16$-dial (5) and labda-8(17),12-diene-15,16-dial (8) with two hydrogen bonds. 4-(3,4-dimethoxy-trans-cinnamoyl)-trans-cinnamic acid (2), isocoronarin $D(3)$, quercetin (4), and galangin (7) formed only one hydrogen bond whereas no hydrogen bonding was noted for galanolactone (1), $\beta$-sitosterol (12), and 7(4-Hydroxy-3-methoxyphenyl)-1-phenylhept-4-en-3-one (9). In addition, compounds 1, 2, $\mathbf{7}$, and $\mathbf{8}$ yielded four interactions with the side chain residues, followed by compounds $\mathbf{3}$ and $\mathbf{5}$ with three interactions, $\mathbf{6 , 9}$, and $\mathbf{1 0}$ with two interactions, and lastly compound $\mathbf{4}$ with only one interaction.

Overall, seven of the ten top-ranking compounds displayed at least one hydrogen bond to the key amino acid residues on the active site of aromatase while all ten compounds showed at least one interaction with the side residues. Several residues in the active pocket also bound to the top ligands either via alkyl, pi-alkyl, or hydrophobic interactions. These interactions are prerequisites for the specific binding of a ligand to aromatase which may elicit a biological activity. It can be suggested that these compounds may bind to the active site and nearby pockets and possibly induce changes in the sensitive molecular structures which may interfere with the intricate process of aromatization, thereby inhibiting production of estrogens and consequently lowering the risk of 
developing hormone-sensitive breast cancer in postmenopausal women (Park et al. 2013; de Leon et al. 2021; Giampetro et al. 2021).

\section{In silico ADME, pharmacokinetic profiling, and drug-likeness analysis}

To assess druggability of top compounds, their ADME and pharmacokinetic profiles were predicted in silico. All top-binding compounds were highly druggable as correlated with their favorable ADME (absorption, distribution, metabolism, excretion) results with at most one violation to Lipinski's rule of five. Meanwhile, four compounds $(\mathbf{2}, \mathbf{4}, \mathbf{7}$, and 10 ) showed non-permeability to the blood-brain barrier. All ten compounds except $\beta$-sitosterol (5) exhibited high gastrointestinal absorption, and good fat solubility properties (Figure 3, Table 3).

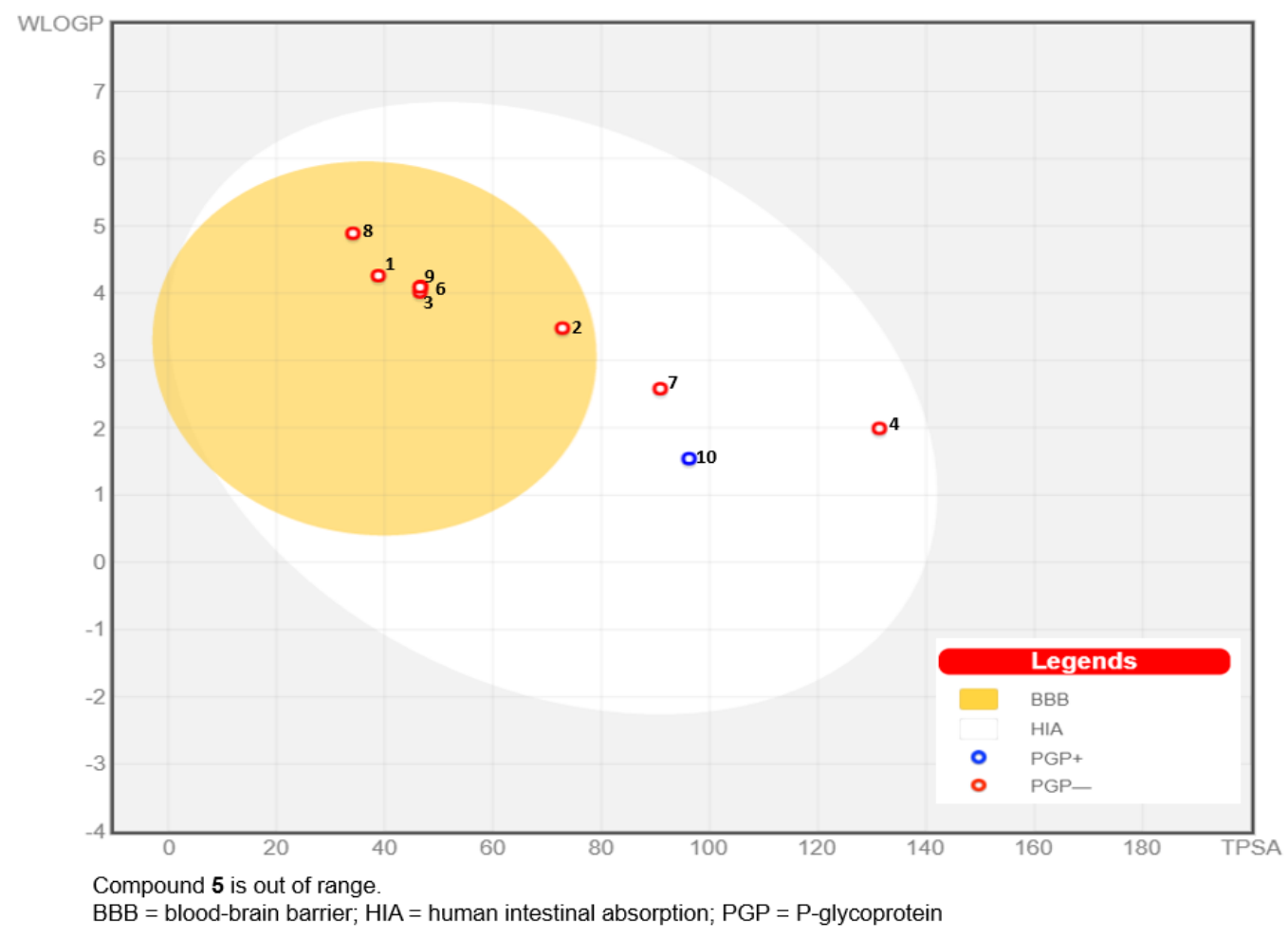

Figure 3. BOILED-Egg of top-ranking compounds showing blood-brain barrier permeability and predicted human intestinal absorption of top-ranking compounds. 
Table 3. Drug-likeness and pharmacokinetic profile of top compounds according to Lipinski's rule of five.

\begin{tabular}{|c|c|c|c|c|c|c|c|c|}
\hline \multirow{3}{*}{$\begin{array}{c}\text { Cpd } \\
\#\end{array}$} & \multirow{3}{*}{$\begin{array}{c}\text { Molecular } \\
\text { Weight } \\
\text { (<500 g/mol) }\end{array}$} & \multirow{3}{*}{$\begin{array}{l}\text { H-bond } \\
\text { donors } \\
(<5)\end{array}$} & \multirow{3}{*}{$\begin{array}{l}\text { H-bond } \\
\text { acceptors } \\
(<10)\end{array}$} & \multirow{3}{*}{$\begin{array}{l}\text { Lipophilicity } \\
(\mathrm{MLog} P<5)\end{array}$} & \multirow{3}{*}{$\begin{array}{l}\text { Lipinski } \\
\text { violations }\end{array}$} & \multirow{3}{*}{$\begin{array}{l}\text { Drug- } \\
\text { likeness }\end{array}$} & \multicolumn{2}{|c|}{$\begin{array}{c}\text { Pharmacokinetic } \\
\text { absorption/ } \\
\text { permeability }\end{array}$} \\
\hline & & & & & & & & \\
\hline & & & & & & & GI & $\begin{array}{l}\text { Blood } \\
\text { Brain } \\
\text { Barrier }\end{array}$ \\
\hline 1 & 318.45 & 0 & 3 & 3.75 & None & Yes & High & Yes \\
\hline 2 & 338.35 & 1 & 5 & 2.34 & None & Yes & High & Yes \\
\hline 3 & 318.45 & 1 & 3 & 3.66 & None & Yes & High & Yes \\
\hline 4 & 302.24 & 5 & 7 & -0.56 & None & Yes & High & No \\
\hline 5 & 414.71 & 1 & 1 & 6.73 & 1 (MLogP) & Yes & Low & No \\
\hline 6 & 318.45 & 0 & 3 & 2.85 & None & Yes & High & Yes \\
\hline 7 & 270.24 & 3 & 5 & 0.52 & None & Yes & High & No \\
\hline 8 & 302.45 & 0 & 2 & 3.64 & None & Yes & High & Yes \\
\hline 9 & 310.39 & 1 & 3 & 3.36 & None & Yes & High & Yes \\
\hline 10 & 302.28 & 3 & 6 & 0.15 & None & Yes & High & No \\
\hline
\end{tabular}




\section{CONCLUSION}

This study reported the in silico inhibitory activity of the constituents of the Philippine medicinal plant Alpinia galanga against human placental aromatase, a pharmaceutical target in estrogen-dependent breast cancer. Results of molecular docking studies indicate the potential of $A$. galanga phytoconstituents namely galanolactone (1), 4-(3,4-dimethoxytrans-cinnamoyl)-trans-cinnamic acid (2), isocoronarin $D(3)$, quercetin (4), $\beta$-sitosterol (5), (E)-8ß,17-epoxylabd-12-ene-15,16-dial (6), galangin (7), labda-8(17),12-diene15,16-dial (8), 7-(4-Hydroxy-3-methoxyphenyl)-1-phenylhept-4-en-3-one (9), and 3,5,7trihydroxy-4-methoxyflavanone (10) for discovering new anti-breast cancer agents and their proposed binding mechanisms in the target protein active site and its side residues. All compounds were also predicted in silico to be highly druggable. The present study also corroborates with previously reported in vitro pro-apoptotic effects of $A$. galanga ethanolic extracts against a breast cancer-derived cell line in a concentration- and timedependent manner (Samarghandian et al. 2014). Considering the overall results, $A$. galanga compounds may serve as natural product-based templates for new generation aromatase inhibitors.

\section{STATEMENT ON CONFLICT OF INTEREST}

None

\section{REFERENCES}


ADHIKARI N, AMIN SA, SAHA A, JHA T. 2017. Combating breast cancer with nonsteroidal aromatase inhibitors (NSAls): Understanding the chemico-biological interactions through comparative SAR/QSAR study. Eur J Med Chem 137: 365-438.

American Cancer Society. 2020. Cancer. Retrieved from https://www.cancer.org/cancer/breast-cancer/about/what-is-breast-cancer.html

AMIR W, SERUGA B, NIRAULA S, CARLSSON L, OCANA A. 2011. Toxicity of adjuvant endocrine therapy in postmenopausal breast cancer patients: a systematic review and metaanalysis. J Natl Cancer Inst 103: 1299-1309.

BRUEGGEMEIER RW, RICHARDS JA, JOOMPRABUTRA S, BHAT AS, WHETSTONE JL. 2001. Molecular pharmacology of aromatase and its regulation by endogenous and exogenous agents. J Steroid Biochem Mol Biol 79(1-5): 75-84.

CHUMSRI S, HOWES T, BAO T, SABNIS G, BRODIE A. 2011. Aromatase, aromatase inhibitors, and breast cancer. J Steroid Biochem Mol Biol 125(1-2): 13-22.

DE LEON VNO, MANZANO JAH, PILAPIL DYH, FERNANDEZ RAT, CHING JKAR, QUIMQUE MTJ, AGBAY JCM, NOTARTE KIR, MACABEO APG. 2021. Anti-HIV reverse transcriptase plant polyphenolic natural products with in silico inhibitory properties on seven non-structural proteins vital in SARS-CoV-2 pathogenesis. J Genet Eng Biotechnol 19(1): 1-17.

Department of Health, Philippines. 2012. Philippine Cancer Control Program. Retrieved from https://doh.gov.ph/philippine-cancer-control-program 
FERNANDEZ RA, QUIMQUE MT, NOTARTE KI, MANZANO JA, PILAPIL IV DY, DE LEON VN, SAN JOSE JJ, VILLALOBOS O, MURALIDHARAN NH, GROMIHA MM, BROGI S, MACABEO APG. 2021. Myxobacterial depsipeptide chondramides interrupt SARS-CoV-2 entry by targeting its broad, cell tropic spike protein. J Biomol Struct Dyn 112.

GHOSH D, GRISWOLD J, ERMAN M, PANGBORN W. 2009. Structural basis for androgen specificity and oestrogen synthesis in human aromatase. Nature 457(7226): 219-223.

GIAMPIETRO L, GALLORINI M, GAMBACORTA N, AMMAZZALORSO A, DE FILIPPIS B, DELla VAlLe A, FANTACUZZI M, MACCALLINI C, MOLLICA A, CATALDI A, NICOLOTTI O, AMOROSO R. 2021. Synthesis, structure-activity relationships and molecular docking studies of phenyldiazenyl sulfonamides as aromatase inhibitors. Eur $\mathrm{J}$ Med Chem 224: 113737.

KIM Y, YOO KY, GOODMAN MT. 2015. Differences in incidence, mortality and survival of breast cancer by regions and countries in Asia and contributing factors. Asian Pac $\mathrm{J}$ Cancer Prev 16(7): 2857-2870.

LEECHAISIT R, PINGAEW R, PRACHAYASITTIKUL V, WORACHARTCHEEWAN A, PRACHAYASITTIKUL S, RUCHIRAWAT S, PRACHAYASITTIKUL V. 2019. Synthesis, molecular docking, and QSAR study of bis-sulfonamide derivatives as potential aromatase inhibitors. Bioorg Med Chem 27(19): 115040.

LONNING PE, EIKESDAL HP. 2013. Aromatase inhibition 2013: clinical state of the art and questions that remain to be solved. Endocr Relat Cancer 20: R183-201. 
MACABEO APG, CRUZ AJC, NARMANI A, ARZANLOU M, BABAI-AHARI A, PILAPIL LAE, GARCIA KYM, HUCH V, STADLER M. 2020. Tetrasubstituted $\alpha$-pyrone derivatives from the endophytic fungus, Neurospora udagawae. Phytochem Lett 35:147-151.

MACABEO APG, LETADA AG, BUDDE S, FADERL C, DAHSE HM, FRANZBLAU SG, ALEJANDRO GJD, PIERENS GK, GARSON MJ. 2017. Antitubercular and cytotoxic chlorinated seco-cyclohexenes from Uvaria alba. J Nat Prod 80(12): 3319-3323.

MACABEO APG, LOPEZ ADA, SCHMIDT S, HEILMANN J, DAHSE HM, ALEJANDRO GJD, FRANZBLAU SG. 2014. Antitubercular and cytotoxic constituents from Goniothalamus gitingensis. Rec Nat Prod 8(1): 41.

MAGPANTAY HD, MALALUAN IN, MANZANO JAH, QUIMQUE MT, PUEBLOS KR, MOOR N, BUDDE S, BANGCAYA PS, LIM-VALLE D, DAHSE HM, KHAN A, WEI DQ, ALEJANDRO GJD, MACABEO APG. 2021. Antibacterial and COX-2 inhibitory tetrahydrobisbenzylisoquinoline alkaloids from the Philippine medicinal plant Phaeanthus ophthalmicus. Plants 10(3): 462.

MALALUAN IN, MANZANO JAH, MUÑOZ JER, BAUTISTA TJL, DAHSE HM, QUIMQUE MTJ, MACABEO APG. 2022. Antituberculosis and Antiproliferative Activities of the Extracts and Tetrahydrobisbenzylisoquinoline Alkaloids from Phaeanthus ophthalmicus: In Vitro and In Silico Investigations. Philipp J Sci 151(1): 371-381.

PARK J, CZAPLA L, AMARO RE. 2013. Molecular simulations of aromatase reveal new insights into the mechanism of ligand binding. J Chem Inf Model 53(8): 2047-2056. 
PETTERSEN EF, GODDARD TD, HUANG CC, COUCH GS, GREENBLATT DM, MENG EC, FERRIN TE. 2004. UCSF Chimera-A visualization system for exploratory research and analysis. J Comput Chem 25(13): 1605-1612.

PHUKHAMSAKDA C, MACABEO APG, HUCH V, CHENG T, HYDE KD, STADLER M. 2019. Sparticolins A-G, biologically active oxidized spirodioxynaphthalene derivatives from the ascomycete Sparticola junci. J Nat Prod 82(10): 2878-2885.

QUIMQUE MTJ, MANDIGMA MJP, LIM JAK, BUDDE S, DAHSE HM, VILLAFLORES OB, HALLARE AV, MACABEO APG. 2020a. Synthesis, Characterization, and Molecular Docking Studies of N-Acylated Butyro and Valerolactam Derivatives with Antiproliferative and Cytotoxic Activities. Lett Drug Des Discov 17(6): 725-730.

QUIMQUE MTJ, NOTARTE KIR, FERNANDEZ RAT, MENDOZA MAO, LIMAN RAD, LIM JAK, PILAPIL LAE, ONG JKH, PASTRANA AM, KHAN A, WEI DQ, MACABEO APG. 2020b. Virtual screening-driven drug discovery of SARS-CoV2 enzyme inhibitors targeting viral attachment, replication, post-translational modification and host immunity evasion infection mechanisms. J Biomol Struct Dyn 1-18.

ROY PP, ROY K. 2010. Molecular docking and QSAR studies of aromatase inhibitor androstenedione derivatives. J Pharm Pharmacol 62(12): 1717-1728.

SAMARGHANDIAN S, HADJZADEH MAR., AFSHARI JT, HOSSEINI M. 2014. Antiproliferative activity and induction of apoptotic by ethanolic extract of Alpinia galanga rhizhome in human breast carcinoma cell line. BMC Complement Altern Med 14(1): 1-9. 
XIAO-LU ZHU, MING-HUA YANG, JIAN-GUANG LUO, HUANG XF, LING-YI KONG. 2009. A new phenylpropanoid from Alpinia galanga. Chin J Nat Med 7(1): 19-20.

YADAV MR, BARMADE MA, TAMBOLI RS, MURUMKAR PR. 2015. Developing steroidal aromatase inhibitors-an effective armament to win the battle against breast cancer. Eur $\mathrm{J}$ Med Chem 105: 1-38.

YANG J, ROY A, ZHANG Y. 2013. Protein-ligand binding site recognition using complementary binding-specific substructure comparison and sequence profile alignment. Bioinformatics 29(20): 2588-2595.

YOULDEN DR, CRAMB SM, YIP CH, BAADE PD. 2014. Incidence and mortality of female breast cancer in the Asia-Pacific region. Cancer Biol Med 11(2): 101.

ZHANG WJ, LUO JG, KONG LY. 2016. The genus Alpinia: a review of its phytochemistry and pharmacology. World J Tradit Chin Med 2(1): 26.

WANG J, WANG W, KOLLMAN PA, CASE DA. 2006. Automatic atom type and bond type perception in molecular mechanical calculations. J Mol Graph Model 25(2): 247-260. 